Lambeek, L.C., Tulder, M.W. van, Swinkels, I.C.S., Koppes, L.L., Anema, J.R., Mechelen, W. vapn The trend in total cost of back pain in The Netherlands in the period 2002-2007. Spine: 2011, 36(13), 1050-1058

\begin{tabular}{|l|l|}
\hline $\begin{array}{l}\text { Postprint } \\
\text { Version } \\
\text { Journal website }\end{array}$ & 1.0 \\
& $\begin{array}{c}\text { http://journals.lww.com/spinejournal/Abstract/publishahead/The_trend_in_total } \\
\text { cost_of_back_pain_in_The.99235.aspx }\end{array}$ \\
\hline Pubmed link & http://www.ncbi.nlm.nih.gov/pubmed/21150697 \\
\hline DOI & $10.1097 /$ BRS.0b013e3181e70488 \\
\hline
\end{tabular}

This is a NIVEL certified Post Print, more info at http://www.nivel.eu

\title{
The Trend in Total Cost of Back Pain in the Netherlands in the Period 2002 to 2007
}

LAMBEEK, LUDEKE C. PHD ${ }^{*}{ }^{* \dagger}$; VAN TULDER, MAURITS W. MD ${ }^{\ddagger}$; SWINKELS, IlSE C.S. PHD ${ }^{\S}$; KOPPES, LANDO L.J. PHD"; ANEMA, JOHANNES R. MD, PHD ${ }^{*,+[/ /]}$; VAN MECHELEN, WILLLEM MD, PHD ${ }^{*},+,[/ /]$

*EMGO Institute for Health and Care Research, Department of Public and Occupational Health, VU University Medical Center, Amsterdam, the Netherlands;

${ }^{\dagger}$ Research Center Physical Activity, Work and Health, TNO-VU-University Medical Center, Amsterdam, the Netherlands;

${ }^{\ddagger}$ Department of Health Sciences and EMGO Institute for Health and Care Research, Faculty of Earth and Life Sciences, VU University Amsterdam, Amsterdam, the Netherlands;

$\S$ NIVEL, Netherlands Institute for Health Services Research, Utrecht, the Netherlands;

"Division of Work and Employment, TNO Quality of Life, Hoofddorp, the Netherlands;

${ }^{[/ /}$Research Center for Insurance Medicine AMC-UWV-VU University Medical Center, Amsterdam, the Netherlands.

\section{ABSTRACT}

Study Design. Cost of illness study.

Objective. To investigate the total costs of back pain in the Netherlands over the years 2002 to 2007.

Summary of Background Data. In 1991, the cost of back pain to the Dutch society was estimated at [Euro sign]4.2 billion. In the last two decades, new laws regarding health insurance and sickness benefits and new guidelines for health care professionals have been introduced and may have affected the societal costs of back pain in the Netherlands.

Methods. We conducted a cost-of-illness study in which we gathered relevant available data from national registries, reports of research institutes, descriptive studies, and occupational health care authorities to estimate the total cost of back pain to the Dutch society for the years 2002 to 2007.

Results. The total costs of back pain decreased from [Euro sign]4.3 billion in 2002 to [Euro sign]3.5 billion in 2007. The share of these costs was about $0.9 \%$ of the gross national product (GNP) in 2002 and $0.6 \%$ of GNP in 2007. The ratio between direct and indirect costs did not change noticeably over the years, that is, $12 \%$ for direct and $88 \%$ for indirect costs.

Conclusions. The total societal costs of back pain have decreased since 1991 and also between 2002 and 2007. Although Dutch policy interventions to lower the indirect costs seem to be successful in the last decades, costs of back pain 
Lambeek, L.C., Tulder, M.W. van, Swinkels, I.C.S., Koppes, L.L., Anema, J.R., Mechelen, W. vapn The trend in total cost of back pain in The Netherlands in the period 2002-2007. Spine: 2011, 36(13), 1050-1058

are still substantial, and indirect costs represent the majority of these costs. Policy interventions and implementation of cost-effective interventions focusing on return-to-work management for back pain in health care is important to further decrease the economic burden of back pain on society.

Back pain is a major health and economic problem for society. In Western countries, reported point prevalence varies from $12 \%$ to $30 \% .{ }^{1}$ On the basis of only demographic developments, the expectation is that the absolute number of persons with back problems will increase by $7 \%$ between 2005 and 2025 . $^{2}$ The impact of back pain on society can be estimated by examining the costs. A recent review of cost of illness studies showed that costs because of back pain ranged from [Euro sign]116 per capita in Belgium to [Euro sign]209 per capita in Sweden. ${ }^{3}$ But outside Europe, low back pain is a massive health problem with a significant economic burden. In the United Stated, approximately one quarter of adults reported low back pain lasting at least 1 whole day in the past 3 months. ${ }^{4}$ In Australia, total cost of low back pain was estimated AU \$9.17 billion, which was AU \$474 per capita. ${ }^{5}$

In 1991, the financial burden of back pain on the Dutch society was assessed to be US $\$ 4.6$ billion equating to US $\$ 307$ per capita. ${ }^{6}$ In comparison with other countries, most of these costs were related to production losses or disability. ${ }^{3}$ Since 1991, many changes have been made in the social security system as well as in the health care system in the Netherlands. For the social security system, new laws have been introduced in the Netherlands like in most industrialized countries in the world aiming to reduce the number of persons receiving a sickness benefit or disability pension. ${ }^{1}, 7$ The health care system has also changed in recent years. First, the health care insurance system was transformed in 2006 because of the increasing demand on health care. This revision included a change in reimbursement of interventions within the Dutch public health insurance system. Second, evidence-based medicine has become the new paradigm, and within this framework, clinical, and primary care practice guidelines for low back pain have emerged aiming to achieve effective and efficient patient care. ${ }^{8}{ }^{10}$ The first Dutch back pain guideline for general practitioners was published in 1996, and several others have been published and updated since then. Third, numerous interventions for treating back complaints have emerged. Fourth, registries of health care use were introduced, for example, a database to register the care given by general practitioners (since 1991) and allied health care professionals (since 2001).

It should be questioned if the reported costs of back pain of 1991 are still representative. Therefore, in this study, we reassessed the financial burden of back pain on the Dutch society and the configuration of the different costs. This cost-of-illness study can indicate the potential scope in the financial burden of back pain and can help in resetting the main targets of health research and policy measures.

\section{MATERIALS AND METHODS}

\section{Cost of Illness}

In this study, we used the societal perspective to estimate the total costs related to back pain in the Netherlands yearly for the years 2002 to 2007. These years were studied because relevant data were not available before 2002 and after 2007. The costs are presented in Euros, and cost indexation was used for each year with 2000 as the base year. The extrapolation of the costs to the Dutch society is described in Appendix 1 (see supplemental digital content, Appendix 1 at http://links.lww.com/BRS/A508 ).

\section{Data Sources}

To identify all costs because of back pain in the Netherlands, we searched for data in national registries, ${ }^{11}{ }^{15}$ reports of research institutes, ${ }^{16}$ descriptive studies, ${ }^{17},{ }^{18}$ and occupational health care authorities $\left({ }^{\text {Table } 1}\right.$ ). Previous research has shown that these sources 
Lambeek, L.C., Tulder, M.W. van, Swinkels, I.C.S., Koppes, L.L., Anema, J.R., Mechelen, W. vapn The trend in total cost of back pain in The Netherlands in the period 2002-2007. Spine: 2011, 36(13), 1050-1058

are representative for the Dutch population and that their reliability is good. ${ }^{19},{ }^{20}$ The data sources used in this study have used several classification systems. To make data comparable, we selected all diagnosis codes related to back pain from different classification systems $\left({ }^{\text {Table } 2}\right)$.

\section{Direct Costs}

Direct costs can be divided in direct medical and direct nonmedical costs. Direct medical costs comprised hospital care cost, medication, general practitioner costs, allied health care costs, and home care costs. Because there is no registration available for the use of home care, these costs were not included in the study.

Direct nonmedical costs are those that related to goods and services consumed directly because of the illness but are not considered to be health care related. They include, for example, not only travel costs to attend health care professionals but also alternative medicine and informal help. Because there is no registration available covering direct nonmedical cost, these costs were not included in the study.

\section{Hospital Care Costs}

Hospital care includes inpatient care, outpatient care, medical procedures, and diagnostic tests. To estimate the volume of hospital care, we used the National Medical Registration of Dutch hospitals (LMR), ${ }^{14}$ the Netherlands Information Network of General Practice (LINH), ${ }^{15}$ the Dutch national surveys of general practice (DNSGP), ${ }^{17}$ and a descriptive study of health care utilization of the Dutch patients with back pain. ${ }^{18}$ To determine the costs, we used the standard costs according to the Dutch Manual for Costing and the tariffs set by National Health tariffs Authority (see ${ }^{\text {Table }}{ }^{1}$ ).

\section{Inpatient Care}

In the Netherlands, we have academic and general hospitals. The LMR showed that $10 \%$ of all inpatient care takes place in an academic hospital and $90 \%$ in a general hospital. The assumption was made that there was no difference in the relative number of patients with back pain visiting the hospitals. The costs of care in an academic hospital are higher compared with a general hospital. The costs of inpatient care were estimated by multiplying the total number of days of inpatient and care with the relevant cost prices taking into account the ratio between both categories of hospitals.

\section{Outpatient Care}

No national database includes outpatient consultations. To approximate the number of outpatient consultations, we used the data source LMR for the number of medical procedures. The assumption was made that on average, patients were seen twice by their medical specialists. ${ }^{16}$ The database of an academic hospital located in Amsterdam, which registers all treatments in that hospital, showed that $10 \%$ to $25 \%$ of patients, who consulted an outpatient clinic, were treated with a medical procedure. Being conservative, we multiplied the number of medical procedures with four to obtain the number of outpatient consultations. The costs of outpatient consultation were estimated by multiplying the number of outpatient consultations with the tariff of a medical specialist.

\section{Medical Procedure Costs}

The LMR registers the number of medical procedures performed in all Dutch hospitals. These procedures are categorized in 12 main operation categories, for example, laminectomy and spondylodesis. The costs of medical procedures by medical specialists were estimated by multiplying the total number of medical procedures for back pain performed in the Dutch hospitals with the relevant tariffs. The tariffs used included those for the medical procedure, medical specialist, and anesthesiology.

\section{Diagnostic Test Costs}

Because of lack of a central register, medical examinations costs could not be assessed directly. On the basis of a descriptive study, ${ }^{18}$ we calculated that $6 \%$ was referred for 
Lambeek, L.C., Tulder, M.W. van, Swinkels, I.C.S., Koppes, L.L., Anema, J.R., Mechelen, W. vapn The trend in total cost of back pain in The Netherlands in the period 2002-2007. Spine: 2011, 36(13), 1050-1058

radiograph, $1.2 \%$ for magnetic resonance imaging, $1.2 \%$ for computed tomography, and for $1.7 \%$ of the patients a laboratory test was carried out. We used the data of LINH to estimate the number of visits to a general practitioner by patients with back pain and extrapolated these visits to the Dutch population. To determine the cost of medical examinations, we multiplied the total number of medical examinations with the relevant cost prices of the examinations.

\section{Drug Costs}

Drug costs related to back pain consist of prescribed medication and out-of-pocket medication. No data are available for out-of-pocket medication. Consequently, the latter costs are not included. To estimate the costs of prescribed medication, we combined the data sources DNSGP and LINH. LINH registers the number of prescriptions because of back pain provided by general practitioners per 1000 Dutch inhabitants. The number of prescriptions was extrapolated to the Dutch population (see supplemental digital content, Appendix 1 at http://links.lww.com/BRS/A508)

\section{[TABLE 1]}

The DNSGP reported that the distribution of prescription for back pain is mostly nonsteroidal anti-inflammatory drugs (i.e., diclofenac and ibuprofen) (30.1\%), followed by benzodiazepine (5.8\%), paracetamol (5.8\%), and opioids (i.e., tramadol) (4.7\%). We estimated the volume of drug use by multiplying the number of prescriptions extrapolated to the Dutch population, which were extracted from LINH, with the percentage of the different category of prescription reported in DNSGP. The drug costs were calculated by multiplying the volume of drug use with the cost price of each prescription. ${ }^{21}$ The volume of drug use was estimated under the assumption that the daily dosage of every medication was four times multiplied with the number of days of drug intake, which was assumed to be $14 .^{22}$

\section{[TABLE 2]}

\section{General Practice Costs}

Since general practitioner visits were not nationally registered, we used the LINH network, which is representative for the Dutch population. LINH documents the total number of visits because of back pain per 1000 Dutch inhabitants. To calculate the visits to a general practitioner for the Dutch society, weextrapolated the visits because of back pain by multiplying the number of visits documented in the LINH network per 1000patients with the total Dutch population (see supplemental digital content, Appendix 1 at http://links.lww.com/BRS/A508 ).To estimate the costs related to general practice, we multiplied the total number of visits because of back pain with the standard cost price for a visit to a general practitioner.

\section{Allied Health Care Costs}

Physical therapy, exercise therapy (Cesar/Mensendieck), and manual therapy are the most commonly used types of allied health care for back pain in the Netherlands.18 Because of lack of a central register for allied health care, we used the data source National Information Service for Allied Health Care (LIPZ). LIPZ exists since 2001 and registers information of physical and exercise therapies. Data before 2003 are less accurate. We assumed that allied health care in 2002 was comparable with 2003. To estimate the volume of allied health care in the Netherlands, we multiplied the average number of treatments per LIPZ practice with the total number of practices in the Netherlands (see supplemental digital content, Appendix 1 at http://links.lww.com/BRS/A508 ).The costs of physical and exercise therapies for back pain were estimated by multiplying the number of treatments with the standard cost price. To estimate the costs related to manual therapy treatment, we used the data of LINH and the 
Lambeek, L.C., Tulder, M.W. van, Swinkels, I.C.S., Koppes, L.L., Anema, J.R., Mechelen, W. vapn The trend in total cost of back pain in The Netherlands in the period 2002-2007. Spine: 2011, 36(13), 1050-1058

standard cost price for a manual therapy consultation. We made the assumption that out of patients with back pain who were referred by their general practitioner, $15 \%$ was referred to a manual therapist. ${ }^{18}$ Another assumption made was that the average number of manual therapy treatment sessions for back pain is three visits.

\section{Indirect Costs}

Production losses and costs related to society due to morbidity and mortality are considered indirect costs of the disease. ${ }^{23}$ Because of the negligible risk of mortality of back pain, the costs of mortality were not estimated. In the Netherlands, an extensive social insurance system exists to provide economic support to workers in case of sickness or disability. In case of sickness, the standard sickness benefits take the form of sick pay administered by the employer. The sickness benefit is provided during the first 52 weeks of illness. From January 2004, this wage payment period was prolonged to 104 weeks. Under the Dutch law, the level of sick pay is at least $70 \%$ of the given worker's salary and is at least social minimum. In practice, most employers pay $100 \%$ of worker's salary.

Workers can apply for a disability pension covered by the Employee Disability Insurance Act when the sickness absence period endures the given period.

\section{Production Losses Costs}

Costs of production losses because of sick leave from low back pain were calculated using the Human Capital Approach. Total costs of disablement were estimated by multiplying the net number of days of work disability due of back pain with the mean daily wages per person, taking into account sex and age. To estimate the costs related to production losses because of back pain, we used the data of one Dutch occupational health service (ArboNed, Utrecht, the Netherlands). ArboNed covers about $15 \%$ of the Dutch working population. To present the production loss for the Dutch society, we extrapolated the total days of disablement by dividing 100 by 15 . The assumption was made that absenteeism among selfemployed is equal to absenteeism among employed people.

\section{Disability Costs}

Costs for disability pensions were obtained from UWV, the Dutch Social Security Agency. The UWV registers all diagnosis-specific disability data and their payments under the disability insurance act on a national basis. There are disability pensions for employed workers, self-employed workers, and people younger than 18 years who are disabled. Besides, there is a group of people (9.4\% of the Dutch working population) who do not receive employer-paid sick pay for 2 years before being granted a disability benefit. This group includes people on temporary contracts who lost their job during the 2 years. The UWV has the same responsibility for these workers as employers have for their employees. Costs for this group were also included.

\section{RESULTS}

Total costs for the Dutch society because of back pain were calculated yearly for the period 2002 to 2007. The annual costs per cost category are presented in Table 3 for the years 2002 to 2007. Figure 1 gives an impression of the distribution of the direct and the indirect costs for back pain. To give insight into the estimation of these costs, we here present the results of the year 2007.

\section{Direct Costs}

\section{Inpatient Care}

The total number of inpatient days was 221,810 days. In 2007, the cost price for 1-day care in an academic hospital was [Euro sign]476 and 337 in a general hospital. Total costs for back pain for inpatient care were estimated at [Euro sign]78 million in 2007 (2.2\% of the total costs of back pain). 
Lambeek, L.C., Tulder, M.W. van, Swinkels, I.C.S., Koppes, L.L., Anema, J.R., Mechelen, W. vapn The trend in total cost of back pain in The Netherlands in the period 2002-2007. Spine: 2011, 36(13), 1050-1058

\section{Outpatient Care}

The number of medical procedures for back pain was 30,964 in 2007. With the assumptions that every patient will have two outpatient consultations per medical procedure and that only $25 \%$ of the patients visiting an outpatient clinic would have a medical procedure, the total number of outpatient consultations was estimated 247,712. Multiplied by the mean fee per consult of [Euro sign]18 in 2007, total cost for ambulatory hospital care was estimated at [Euro sign]4 million in 2007 (0.1\% of the total costs of back pain).

\section{Medical Procedures Costs}

The total number of operations for back pain in the Dutch hospitals was 30,032. The total costs of medical procedures were [Euro sign]15,043,708. Total costs of fees regarding medical procedures declared by medical specialists were [Euro sign]5,400,238. Total costs of fees declared by the anesthesiologists were estimated [Euro sign]2,280,131. In total regarding 30,032 operations for the back pain, the costs were estimated at [Euro sign]23 million in 2007 ( $0.7 \%$ of the total costs of back pain).

\section{Diagnostic Test Costs}

A total of 474,382 referrals for patients with back pain were made by general practitioners in 2007. Of these referrals, 28,463 patients were referred for radiograph, 5693 patients for a magnetic resonance imaging, 5693 for a computed tomography, and for 8064 patients, a laboratory test was carried out. In 2007, the cost prices for these examinations were [Euro sign]44, 187, 31, and 23, respectively. Total costs for medical examinations were estimated at [Euro sign]3 million in 2007 ( $0.1 \%$ of the total costs of back pain).

\section{Drug Costs}

LINH reported that 154 patients per 1000 Dutch inhabitants, who had visited their general practitioner because of back pain, received prescribed medication. The number of prescriptions for back pain in general practice on national level was 2,519,131 in 2007. The share of these prescriptions was 758,258 for nonsteroidal anti-inflammatory drugs; 146,110 for benzodiazepine; 143,591 for paracetamol; and 118,400 for opioids. The price we used for each prescription were [Euro sign]18, 21, 10, and 26, respectively. Total costs of prescribed medication by general practitioners were estimated at [Euro sign]21 million in 2007 ( $0.6 \%$ of the total costs of back pain).

\section{General Practice Costs}

In 2007, the tariff for one general practitioner visit was [Euro sign]21. LINH reported a total of 328 visits for back pain per 1000 Dutch inhabitants in 2007. Extrapolated to the Dutch society $(328 / 1000 * 16,357,992)$, the total number of visits to a general practitioner because of back pain was 5,371,801. This resulted in total costs of [Euro sign]113 million (3.2\% of the total costs of back pain).

\section{[TABLE3]}

\section{[FIGURE 1]}

\section{Allied Health Care Costs}

In 2007, the total costs for allied health care were estimated at [Euro sign]232 million, which constitutes a proportion of $6.6 \%$ of the total costs of back pain. These costs were composed of costs of back pain in physical therapy practice ([Euro sign]204 million), in exercise therapy practice ([Euro sign]21 million), and in manual therapy practice ([Euro sign]7 million). 
Lambeek, L.C., Tulder, M.W. van, Swinkels, I.C.S., Koppes, L.L., Anema, J.R., Mechelen, W. vapn The trend in total cost of back pain in The Netherlands in the period 2002-2007. Spine: 2011, 36(13), 1050-1058

The cost price for a physical therapist visit was [Euro sign]24. Within the LIPZ network, patients had visited their physical therapist 68,776 times because of back pain. To extrapolate the number of visits extracted out the LIPZ network to a national level, we multiplied the average number of treatments per LIPZ practice $(68,776 / 38)$ with the total number of practices in the Netherlands (4688). The cost price of one visit to an exercise therapist was [Euro sign]24. A total of 25,310 visits to an exercise therapist were recorded in the LIPZ network. By extrapolating these visits to the Dutch situation, a total of 848,096 visits were estimated. The cost price for a manual therapist visit was [Euro sign]33. LINH had registered that per 1000 Dutch inhabitants, 28 patients with back pain were referred by their general practitioner. Extrapolated to the Dutch society, 68,074 patients had visited a manual therapist with a total number of visits of 206,111.

\section{Indirect Costs}

\section{Production Losses Costs}

The number of sick leave days because of back pain reported by the occupational health service ArboNed was 908,571 days in 2007. Extrapolated to the Dutch working population by $100 / 15$, the total days of sick leave because of back pain were 6,057,140 days. ${ }^{\text {Figure } 2}$ gives an impression for the volume of sick leave in the period 2002 to 2007. The extrapolated costs of production losses for back pain in the Netherlands were estimated at [Euro sign]1699 million in 2007 (48.1\% of the total costs of back pain).

\section{Disability Costs}

The total costs of disability because of back pain were estimated at [Euro sign]1361 million in 2007, which comprises a proportion of $38.5 \%$ of the total costs of back pain. These costs were spent on disability pensions for 94,759 persons with back pain who received a disability pension for in total 52 million days. The costs of disability can be divided into three categories: (1) disability pension for employed was estimated 1125 million with a mean daily pension of [Euro sign]45, (2) disability pension for self-employed was estimated 66 million with a mean daily pension of [Euro sign]30, and (3) disability pension people under 18 years who are disabled was estimated 12 million with a mean daily pension of [Euro sign]39. A total of [Euro sign]159 million was spent on the group that includes people on temporary contracts who lost their job during the 2 years.

\section{DISCUSSION}

In this study, we have assessed the financial burden of back pain on the Dutch society for the period 2002 to 2007 with a top-down approach. Over time, the total costs of back pain to the Dutch society decreased from [Euro sign]4.3 billion in 2002 to [Euro sign]3.5 billion in 2007. These costs were split unequally between direct costs (11\%-13\%) and indirect costs (87\%-89\%) and equated $0.9 \%$ in 2002 to $0.6 \%$ in 2007 of the gross national product (see supplemental digital content, Appendix 1 at http://links.lww.com/BRS/A508 ).

\section{Comparison With Other Studies}

If we compare the data of this study with the data of $1991,{ }^{6}$ the results of this study indicate for the period 2002 to 2007 higher direct medical cost of back pain with the exception of inpatient care cost, which were 67\% higher in 1991 compared with 2007. Overall, the indirect costs were much lower in this study compared with 1991; overall, 22\% less in 2007 compared with 1991. The difference between this earlier estimate and this study may be not only due to the introduction of new laws regarding health insurance and sickness benefits ${ }^{24},{ }^{25}$ but also due to different assumptions made and the data used. In the last decade, databases that register data related to back pain were set up. This makes the more recent data more reliable than that of 1991. 
Lambeek, L.C., Tulder, M.W. van, Swinkels, I.C.S., Koppes, L.L., Anema, J.R., Mechelen, W. vapn The trend in total cost of back pain in The Netherlands in the period 2002-2007. Spine: 2011, 36(13), 1050-1058

Comparison of the results of this study with international studies is difficult. It should be noticed that for several reasons comparisons between international studies should be made with caution. First, health care systems and social security systems differ between countries. ${ }^{1}$ Second, cost perspectives adopted in studies vary. ${ }^{3}$ Third, case definitions of back pain differ among studies. Finally, the cost categories included differ between studies. However, a recent review identified 27 studies that have previously attempted to estimate direct, indirect, or total costs associated with low back pain. Regardless of the difference in methods used, the studies suggest that by far the largest component of the costs because of back pain for society was lost productivity. ${ }^{3}$ This is inline with the findings of this study.

\section{[FIGURE 2]}

\section{STRENGTHS}

The data of our study are relatively accurate because we were able to use several validated databases that measure data on a national level. Therefore, for most cost categories, no assumptions had to be made. Another strength of this study is the large number of costs categories that was included. Besides the main categories in cost-of-illness studies, we also calculated cost of medication use because of back pain and differentiated in hospital costs and allied health care costs.

\section{Limitations}

Several limitations of this study must be pointed out. First, regarding the estimation of costs of back pain, several assumptions were necessary, which may have caused over- or underestimation. Cost for general practice increased by $95 \%$ in 2006. Because more accurate registration of general practice use was available since 2006, data before 2006 provide probably an underestimation. Also the drug costs may have been underestimated because we did not include the over-the-counter medication. Second, in our study, we had to use various classification systems. The cost categories may therefore not have represented the same diagnoses, but we believe that this discrepancy is only small. Third, some costs were not included in our study because no data were available. A cost-of-illness study conducted in Germany showed that the component direct nonmedical costs (e.g., alternative medicine and informal care) would add another $9.6 \%$ to the total costs for back pain. ${ }^{26}$ Extrapolating this percentage in a simplistic manner to the data of this study, this cost omission may represent an underestimate of about [Euro sign]336 million. Fourth, we used the human capital method to estimate the cost due to production losses since we did not have sick leave data on an individual level. This method may overestimate the production loss costs compared with the use of the friction cost method that takes into account that employees can be replaced after a certain time period. ${ }^{27}$ Studies reported that estimates of work productivity losses with the friction period approach were $30 \%$ to $56 \%$ lower than those with the human capital approach. ${ }^{3}, 7$

\section{Policy Implications}

Moderating the high costs of sickness absence and disability is a key policy concern in many countries. ${ }^{17}$ The results of this study suggest that the Netherlands has a successful disability policy primarily based on reintegration. ${ }^{1}$ During the period 2002 to 2007, sick leave among workers with back pain decreased substantially (25\%) and the number of people receiving a disability pension because of back pain decreased over the years (26\%). Research indicates that this decrease coincided with changes in the management of back pain and with the introduction of new laws regarding sickness benefits. ${ }^{25}$ Despite this decrease in the number of people receiving a disability pension, there is room for more cost savings. Development and evaluation of intervention concerning the social security system, primary prevention, and implementation of evidence-based return-to-work interventions are priorities for future research. The process of return-to-work after ill health has a multifactorial nature, 
Lambeek, L.C., Tulder, M.W. van, Swinkels, I.C.S., Koppes, L.L., Anema, J.R., Mechelen, W. vapn The trend in total cost of back pain in The Netherlands in the period 2002-2007. Spine: 2011, 36(13), 1050-1058

and different "systems," such as the personal, workplace, health care, and insurance system, are involved. ${ }^{1}{ }^{28},{ }^{29}$ This makes research in this field challenging. The interests of the various stakeholders in the Netherlands and other countries can be conflicting. For example, health insurances companies may not want to pay for effective return-to-work interventions because primarily employers/companies will benefit. It is therefore a challenge as well to bring all the relevant stakeholders together for the prevention of disability. Policy interventions are needed to bring the players onside. ${ }^{1}$ In addition, reviews of interventions studies focusing on return-to-work for back pain patients show that there is (moderate) evidence of positive effectiveness for return-to-work. ${ }^{30}{ }^{32}$ The challenge will be to implement these interventions in (occupational) health care.

\section{CONCLUSIONS}

Despite reduction of costs because of back pain for the Dutch society over the past years, the costs remain tremendous. The economic impact is mostly due to the indirect costs of work absenteeism and disability. Recent Dutch policy interventions to lower the indirect costs appear to be successful, but there is still room for cost savings by policy intervention.

\section{Key Points}

The total societal costs of back pain have decreased over the years.

Dutch policy interventions to lower the indirect costs seem to be successful in the last decades; still costs of back pain are substantial and indirect costs represent the majority of these costs.

Policy interventions and implementation of cost-effective interventions focusing on returnto-work management for back pain in health care is important to further decrease the economic burden of back pain on society.

\section{Acknowledgments}

The authors thank Mrs. M. Beentjes (VU Medical Center), Mr. P. Rijnsburger (UWV), Mr. S. Visser (Nivel), Mr. C. Roelen, and Mrs. P. Koopmans (ArboNed) for providing data and information.

\section{REFERENCES}

1. Anema JR, Schellart AJ, Cassidy JD, et al. Can cross country differences in return-to-work after chronic occupational back pain be explained? An exploratory analysis on disability policies in a six country cohort study. J Occup Rehabil 2009;19:419-26.

2. Koes BW, van Tulder MW, Poos MJJC. Neemt het aantal mensen met nek- en rugklachten toe of af? In: Volksgezondheid Toekomst Verkenning, National Kompas Volksgezondheid 2006.

3. Dagenais S, Caro J, Haldeman S. A systematic review of low back pain cost of illness studies in the United States and internationally. Spine J 2008;8:8-20.

4. Deyo RA, Mirza SK, Martin BI. Back pain prevalence and visit rates: estimates from U.S. national surveys, 2002. Spine (Phila Pa 1976) 2006;31:2724-7.

5. Walker BF, Muller R, Grant WD. Low back pain in Australian adults: the economic burden. Asia Pac J Public Health 2003;15:79-87.

6. van Tulder MW, Koes BW, Bouter LM. A cost-of-illness study of back pain in the Netherlands. Pain 1995;62:233-40.

7. Organisation for Economic Co-operation and Development (OECD). Transforming disability into ability. Policies to promote work and income security for disabled people. 2003.

8. Bekkering GE, Hendriks HJM, Koes BW, et al. Clinical guidelines on physiotherapy for low back pain. [In Dutch: KNGF-richtlijn Lage-rugpijn.]. Nederlands Tijdschrift Fysiotherapie 2001.

9. Kwaliteitsinstituut voor de Gezondheidszorg CBO. Clinical guidelines for non-specific low back pain. [In Dutch: Richtlijn aspecifieke lage-rugklachten]. Utrecht, The Netherland:

Kwaliteitsinstituut voor de Gezondheidszorg CBO; 2003. 
Lambeek, L.C., Tulder, M.W. van, Swinkels, I.C.S., Koppes, L.L., Anema, J.R., Mechelen, W. vapn The trend in total cost of back pain in The Netherlands in the period 2002-2007. Spine: 2011, 36(13), 1050-1058

10. Verbeek JH, Anema JR, Everaert CPJ, et al., NVAB-Richtlijn Handelen van de bedrijfsarts bij werknemers met Lage-Rugklachten. Utrecht, The Netherland:

Kwaliteitsbureau NVAB; 2006.

11. Centraal Bureau voor de Statistiek . Available at: http://www.cbs.nl/nl-

NL/menu/themas/arbeid-sociale-zekerheid/publicaties/artikelen/archief/2008/2008-90122wk.htm . Accessed November 5, 2009.

12. Kooijman MK, Swinkels ICS, Leemrijse C, et al., Landelijke Informatievoorziening Paramedische Zorg (LiPZ) [In Dutch]. Utrecht, The Netherland: Prismant; 2009.

13. Prismant. Classification of Procedures (CvV). Standaard classificatie van medisch specialistische verrichtingen [In Dutch]. Urecht, The Netherland: Prismant; 2005.

14. Prismant. Landelijke Medische Registratie 2002-2007; 2009.

15. Verheij RA, Abrahamse H, Davids R, et al., Netherlands Information Network of General Practice: Facts and Figures on Dutch GP Care. Utrecht, The Netherland: Nivel; 2009.

16. Struijs JN, Baan CA, Slobbe LCJ, et al., Koppeling van anonieme huisartsgegevens aan ziekenhuisregistraties. RIVM rapport 282701006/2004. Bilthoven, The Netherland: RIVM; 2004.

17. Cardol M, van Dijk L, de Jong JD, et al., Tweede nationale studie naar ziekten en verrichtingen in de huisartspraktijk. Huisartsenzorg: wat doet de poortwachter? Utrecht/Bilthoven, The Netherland: NIVEL/RIVM; 2004.

18. van Tulder MW, Koes BW, Metsemakers JF, et al. Chronic low back pain in primary care: a prospective study on the management and course. Fam Pract 1998;15:126-32.

19. Paas GRA, Veenhuizen KCW. Research of the reliability of the LMR, report for hospitals. In: Dutch: Onderzoek naar de betrouwbaarheid van de LMR, rapportage voor de ziekenhuizen. Utrecht, The Netherland: Prismant; 2002.

20. Swinkels ICS. Monitoring Physiotherapy Using a National Registration Network; 2008.

21. Z-index. G-Standaard. The Hague: the Netherlands: Z-index; 2006.

22. Health Care Insurance Board. Farmaceutisch Kompas; 2009.

23. Koopmanschap MA, van Ineveld BM. Towards a new approach for estimating indirect costs of disease. Soc Sci Med 1992;34:1005-10.

24. Jehoel-Gijsbers G (Ed.). Beter aan het werk. Trendrapportage ziekteverzuim, arbeidsongeschiktheid en werkhervatting. Den Haag: SCP/CBS/TNO Kwaliteit van Leven; 2007.

25. Steenstra IA, Verbeek JH, Prinsze FJ, et al. Changes in the incidence of occupational disability as a result of back and neck pain in the Netherlands. BMC Public Health 2006;6:190.

26. Wenig CM, Schmidt CO, Kohlmann T, et al. Costs of back pain in Germany. Eur J Pain 2009;13:280-6.

27. Hutubessy RC, van Tulder MW, Vondeling $\mathrm{H}$. Indirect costs of back pain in the Netherlands: human capital or friction cost method? Annu Meet Int Soc Technol Assess Health Care Int Soc Technol Assess Health Care Meet 1996;12.

28. Loisel P, Durand MJ, Berthelette D, et al. Disability Prevention. New paradigm for the management of occupational back pain. Dis Manage Health Outcomes 2001;9:351-60.

29. Waddell G, Burton AK, Aylward M. A biopsychosocial model of sickness and disability. AMA Guides Newsletter. ed. Chicago, IL: American Medical Association; 2008:1-13.

30. Hlobil H, Staal JB, Spoelstra M, et al. Effectiveness of a return-to-work intervention for subacute low-back pain. Scand J Work Environ Health 2005;31:249-57.

31. Karjalainen K, Malmivaara A, van TM, et al. Multidisciplinary biopsychosocial rehabilitation for subacute low back pain in working-age adults: a systematic review within the framework of the Cochrane Collaboration Back Review Group. Spine (Phila Pa 1976) 2001;26:262-9.

32. van Oostrom SH, Driessen MT, de Vet HC, et al. Workplace interventions for preventing work disability. Cochrane Database Syst Rev 2009;CD006955.

33. Oostenbrink JB, Koopmanschap MA, Rutten FF. Standardisation of costs: the Dutch Manual for Costing in economic evaluations. Pharmacoeconomics 2002;20:443-54.

34. Lamberts $\mathrm{H}$, Wood M. International Classification of Primary Care. Oxford, United Kingdom: Oxford University; 1987.

35. Slee VN. The international classification of diseases: ninth revision (ICD-9). Ann Intern Med 1978;88:424-6. 
Lambeek, L.C., Tulder, M.W. van, Swinkels, I.C.S., Koppes, L.L., Anema, J.R., Mechelen, W. vapn The trend in total cost of back pain in The Netherlands in the period 2002-2007. Spine: 2011, 36(13), 1050-1058

36. Ouwehand P, Wouters PHM. Classificaties voor Arbo en SV: classificatie van klachten, ziekten en oorzaken voor bedrijfs- en verzekeringsartsen. Utrecht, the Netherlands: Voorlichtingscentrum Sociale Verzekering; 1997. 
Lambeek, L.C., Tulder, M.W. van, Swinkels, I.C.S., Koppes, L.L., Anema, J.R., Mechelen, W. vapn The trend in total cost of back pain in The Netherlands in the period 2002-2007. Spine: 2011, 36(13), 1050-1058

\section{TABLES AND FIGURES}

Table 1

\begin{tabular}{|c|c|c|}
\hline Cost Categories & Data Sources & Details \\
\hline \multicolumn{3}{|l|}{ Direct costs } \\
\hline \multirow[t]{3}{*}{ Hospital care } & $\begin{array}{l}\text { National Medical Registration } \\
(\mathrm{LM} R)^{14}\end{array}$ & $\begin{array}{l}\text { LMR is a National Medical Register that holds longitudinal data on inpatient } \\
\text { days of care, outpatient days of care, and medical procedures and covers } \\
\text { almost a } 100 \% \text { of the Dutch hospitals since } 1964 \text {. The data are registered ac- } \\
\text { cording to the classification ICD-9. }\end{array}$ \\
\hline & Report of Struijs et $a l^{16}$ & $\begin{array}{l}\text { This report focuses on the health care utilization of chronically ill people by } \\
\text { linking data on referrals by general practitioners (LINH) with data on hospital } \\
\text { utilization in the Netherlands (LMR). }\end{array}$ \\
\hline & Classification of Procedures $\left(\mathrm{CW}^{\prime 3}\right)^{3}$ & $\begin{array}{l}\text { CVV is used in hospital setting classify diagnostic, operative, and therapeutic } \\
\text { procedures. The database registers on a national basis. The data are registered } \\
\text { according to the classification ICD-9. }\end{array}$ \\
\hline \multirow[t]{2}{*}{ General practice } & $\begin{array}{l}\text { Netherlands Information } \\
\text { Network of Ceneral Practice } \\
\text { (LINH) }{ }^{15}\end{array}$ & $\begin{array}{l}\text { LINH is the Netherlands Information Network of Ceneral Practice. The LINH } \\
\text { database holds longitudinal data on consultations, morbidity, prescribing, and } \\
\text { referrals of about } 340,000 \text { individuals since } 1991 \text {. Data are collected in a rep- } \\
\text { resentative network of about } 180 \text { general practitioners and spread throughout } \\
\text { the Netherlands. Data sources are extracted twice a year from the electronic } \\
\text { medical record systems used in the practices to file patient information. The } \\
\text { registration was according to the ICPC. }\end{array}$ \\
\hline & $\begin{array}{l}\text { Dutch national survey of general } \\
\text { practice (DNSCP) }\end{array}$ & $\begin{array}{l}\text { The DNSCP survey includes a detailed study on health and health care of ap } \\
\text { proximately } 400,000 \text { patients registered in } 104 \text { general practices including } \\
195 \text { general practitioners. This study was carried out in } 2000 \text { to } 2002 \text {. }\end{array}$ \\
\hline \multirow[t]{2}{*}{ Allied health care } & $\begin{array}{l}\text { National Information Service for } \\
\text { Allied Health Care (LiPZ) }\end{array}$ & $\begin{array}{l}\text { LiPZ is a nationwide representative automated recording network of physical } \\
\text { therapists, Mensendieck, and Cesar therapists in which ongoing care-related } \\
\text { data are collected since } 2001 \text {. This service collects computerized data on a } \\
\text { continuous basis. The ICPC was used to classify the data. }\end{array}$ \\
\hline & Report of van Tulder et a/s & $\begin{array}{l}\text { Prospective descriptive study involving } 26 \text { general practitioners and } 524 \text { patients } \\
\text { with chronic low back pain. It described the health care utilization in the } \\
\text { Netherlands in the period } 1993 \text { to } 1995 \text {. Health care problems were classi- } \\
\text { fied according to the ICPC. }\end{array}$ \\
\hline \multicolumn{3}{|l|}{ Indirect costs } \\
\hline Production losses & $\begin{array}{l}\text { Occupational Health Service } \\
\text { (ArboNed) }\end{array}$ & $\begin{array}{l}\text { ArboNed holds longitudinal diagnosis-specific sick leave data. ArboNed } \\
\text { represents about } 15 \% \text { of the Dutch population. They use CAS to classify the } \\
\text { sick leave. }\end{array}$ \\
\hline \multirow[t]{2}{*}{ Disability } & $\begin{array}{l}\text { National Institute for Social } \\
\text { Security (UWV) }\end{array}$ & $\begin{array}{l}\text { UWV is the National Institute for Social Security and covers the registration of } \\
\text { diagnosis-specific disability data for } 100 \% \text {. The used classification system was } \\
\text { CAS. }\end{array}$ \\
\hline & Statistics Netherlands (CBS)" & $\begin{array}{l}\text { CBS is the largest provider of reliable on socioeconomic data, which is repre } \\
\text { sentative for the total Dutch population. }\end{array}$ \\
\hline \multicolumn{3}{|l|}{ Tariffs } \\
\hline & Report of Oostenbrink et $a^{\beta 3}$ & $\begin{array}{l}\text { This is a manual report that describes the method to calculate standard costs in } \\
\text { direct and indirect care. Costs presented in the manual are for the years } 2002 \\
\text { and } 2003 \text {. }\end{array}$ \\
\hline & $\begin{array}{l}\text { CTC (Centraal Tarieven } \\
\text { Gezondheidszorg) Statistics } \\
\text { Netherlands }\end{array}$ & $\begin{array}{l}\text { CTC is the National Health Tariffs Authority that declares all tariffs within the } \\
\text { health care sector for the Netherlands. }\end{array}$ \\
\hline & Z-index ${ }^{21}$ & $\begin{array}{l}\text { Z-index is a company since } 1999 \text { that collects, manages, and disseminates data } \\
\text { of all products, which can be obtained at a public pharmacy. }\end{array}$ \\
\hline
\end{tabular}


Lambeek, L.C., Tulder, M.W. van, Swinkels, I.C.S., Koppes, L.L., Anema, J.R., Mechelen, W. vapn The trend in total cost of back pain in The Netherlands in the period 2002-2007. Spine: 2011,

36(13), 1050-1058

Table 2

\begin{tabular}{|c|c|}
\hline \multicolumn{2}{|c|}{ TABLE 2. The Used Codes for Back Pain of Each } \\
Classification System
\end{tabular}

Table 3

\begin{tabular}{|c|c|c|c|c|c|c|}
\hline \multirow[b]{2}{*}{ Year } & 2002 & 2003 & 2004 & 2005 & 2006 & 2007 \\
\hline & \multicolumn{6}{|c|}{ (Cost in millions Euros) } \\
\hline \multicolumn{7}{|l|}{ Direct costs } \\
\hline Inpatient care & 68 & 68 & 73 & 74 & 75 & 78 \\
\hline Outpatient care & 4 & 4 & 5 & 5 & 4 & 4 \\
\hline Medical procedures & 19 & 21 & 23 & 23 & 23 & 23 \\
\hline Diagnostic tests & 4 & 4 & 4 & 4 & 3 & 3 \\
\hline Drug & 17 & 19 & 17 & 18 & 18 & 21 \\
\hline General practice & 58 & 59 & 61 & 61 & 110 & 113 \\
\hline Allied health care & 283 & 283 & 250 & 236 & 246 & 232 \\
\hline \multicolumn{7}{|l|}{ Indirect costs } \\
\hline Production losses & 2267 & 2221 & 2257 & 2052 & 1800 & 1699 \\
\hline Disability & 1561 & 1567 & 1507 & 1431 & 1348 & 1361 \\
\hline Total costs & 4281 & 4246 & 4197 & 3904 & 3627 & 3534 \\
\hline
\end{tabular}

\section{Figure 1}

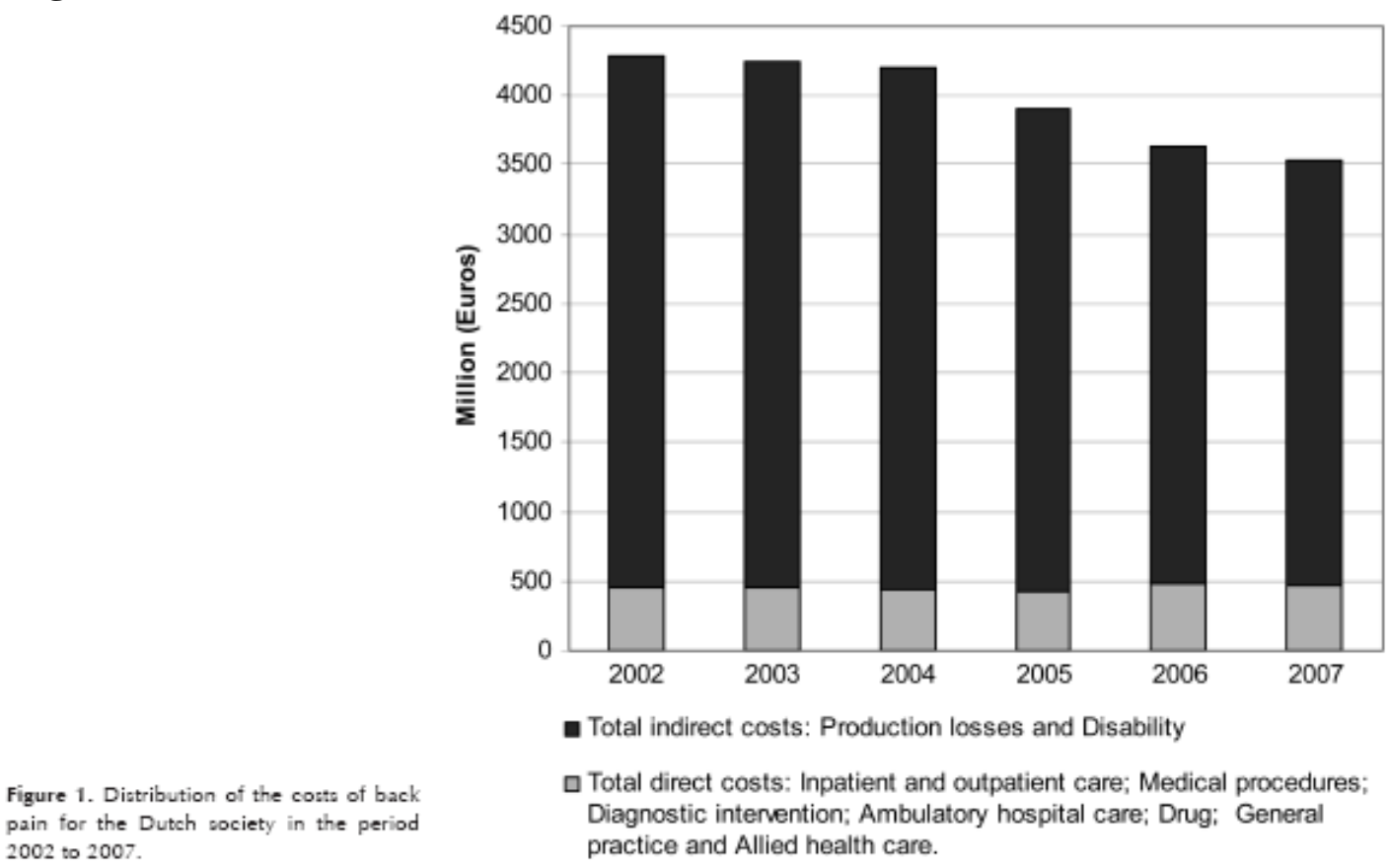


Lambeek, L.C., Tulder, M.W. van, Swinkels, I.C.S., Koppes, L.L., Anema, J.R., Mechelen, W. vapn The trend in total cost of back pain in The Netherlands in the period 2002-2007. Spine: 2011, 36(13), 1050-1058

\section{Figure 2}

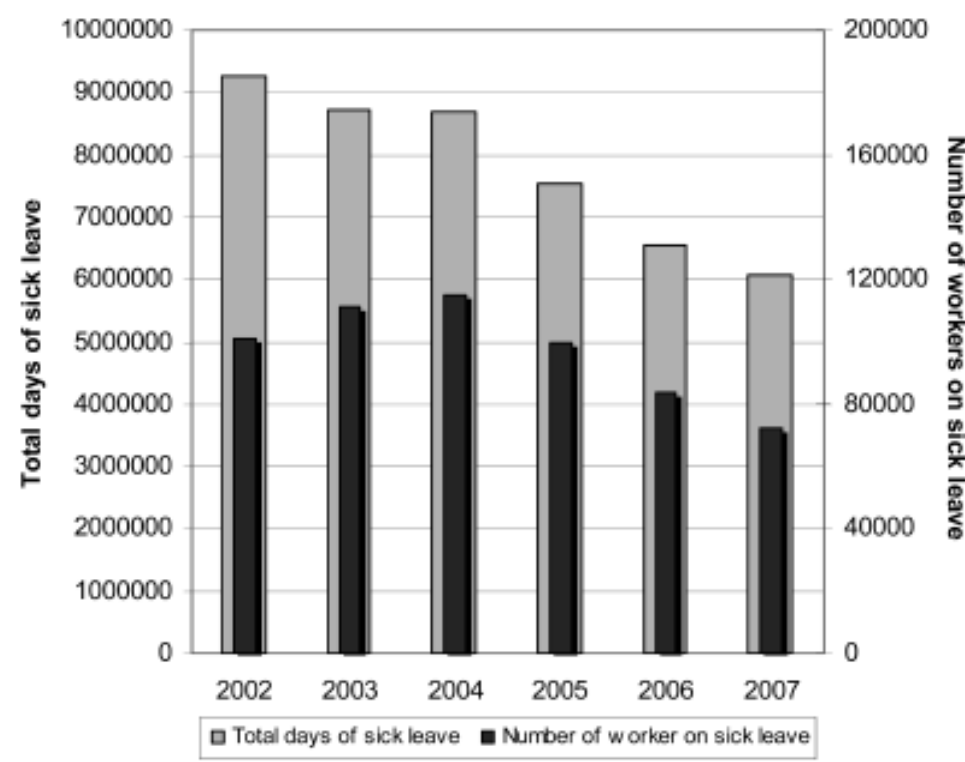

Figure 2. Number of workera on sick leave and the total number of days of aick leave because of back pain for the years 2002 to 2007 . 